\title{
'The Nation will always prevail', Representation, participation and contestation in the Belgian Constitution of 1831
}

\author{
Christophe Maes \\ Postdoctoral researcher, Leuven Centre for Public Law, Faculty of Law, \\ KU Leuven, Tiensestraat 41, box 3441-300o Leuven (Belgium) \\ christophe.maes@kuleuven.be \\ Brecht Deseure \\ Postdoctoral research fellow, Department of Modern Languages, Faculty \\ of Arts and Humanities, King's College London, 22 Kingsway, - London \\ WC2B 6NR (United Kingdom) \\ brecht.deseure@kcl.ac.uk
}

\section{Summary}

The exact nature of the concept of sovereignty enshrined by the Belgian Constitution of 1831 has recently become the object of academic debate. This article takes a stand in this debate by analyzing the representative system instated by the constituent National Congress. It is argued that the congressmen attributed primacy to the legislative Chamber because it concentrated in its midst all the individual wills of the people in order to express the general will or the wish of the Nation. Importantly, though, parliament was not the only representative of the national will, neither was it considered completely self-contained. Parliament's expression of the national will was subject to constant evaluation by public opinion. When the assembly failed to respond to popular grievances, other representatives were qualified to address the issue: the king could disband the Chamber or pronounce his veto when the national interest required it. The jury, assessing press or political related crimes, could correct oppressive governmental action. And if all of this failed - and only then - the nation could ultimately resist and take directly matters in its own hands. Thus, it is argued that the character of sovereignty in the Belgian state system was ultimately popular. 


\section{Keywords}

Constitution - Nation - Sovereignty - Representation - Participation - Belgium

\section{Introduction*}

The nature of political representation has been a core issue in political theory since the early days of modern constitutionalism. Many contemporary legal scholars maintain that the Belgian governmental system, instituted by the Belgian Constitution of 1831 , is exclusively representative and, by consequence, rules out all forms of direct or semi-direct democracy. To this day, article 33 (old art. 25) stipulates that all the state powers emanate from the nation, and that these powers can only be exercised in the manner laid down by the Constitution. According to legal doctrine, the origins of this disposition go back to the 1791 understanding of national sovereignty, as explained by the French legal scholar Carré de Malberg.

In his Contribution à la théorie générale de l'État (1920-1922), Carré de Malberg theorised that the representative regime followed from the principle of national sovereignty ${ }^{1}$, a principle he claimed to find in France's constitutional tradition $^{2}$. With the exception of the French 1793 Constitution, which admitted direct participation of the tangible people, the 'nation' in the French revolutionary constitutions was conceived as an abstract entity ${ }^{3}$. This entity held absolute, unlimited, indivisible and inalienable sovereignty. Consequently, sovereign power could not be claimed by the king, nor by any other (group of) individual $(\mathrm{s})^{4}$.

Given its nature as a mere juridical abstraction, the nation could never will nor act by itself but only through representatives. Carré de Malberg went so far as to argue that the nation was entirely constituted via its 'representative organs'5. The representatives were supposed to independently create the will of

\footnotetext{
* The authors would like to thank Raf Geenens, Stefan Sottiaux and the reviewers of the Tijdschrift voor Rechtsgeschiedenis for their remarks.

1 R. Carré de Malberg, Contribution à la théorie générale de l'Etat, spécialement d'après les données fournies par le droit constitutionnel français, vol. 2, Paris 1922, p. 199.

2 E. Maulin, Carré de Malberg et le droit constitutionnel de la Révolution française, Annales historiques de la Révolution française, 328 (2002), p. 5-25.

3 Carré de Malberg, Contribution (supra, n. 1), vol. 2, p. 228; R. Carré de Malberg, Contribution à la théorie générale de l'Etat: spécialement d'après les données fournies par le droit constitutionnel français, vol. 1, Paris 1920, p. 87 .

4 Carré de Malberg, Contribution (supra, n. 1), vol. 2, p. 176-177.

5 Carré de Malberg, Contribution (supra, n. 1), vol. 2, p. 196-197 and p. 228-229.
} 
the nation ${ }^{6}$, without granting the electorate any possibility of contestation ${ }^{7}$. In consequence, the imperative mandate, which presupposed binding instructions from the electorate, was ruled out ${ }^{8}$. This also led to the possibility of restricting franchise, as sovereignty was not linked to every individual (entailing an individual's right to elect), but to the collective nation. The electorate was only supposed to fulfil a function by designating the elected body 9 . With this represented sovereignty, embodied in the French Constitution of 1791, the modern conception of representation saw the light: the representative's own conviction should be decisive, rather than that of those who elected him.

However, the theory of national sovereignty as formulated by Carré de Malberg is increasingly called into question by public lawyers, legal historians and political theorists. Critics single out the conceptual inconsistency of national sovereignty as well as its lack of historicity ${ }^{10}$. It has been argued that the national sovereignty theory did not originate in the revolutionary period but was only formulated later by the French Doctrinaire liberals, somewhere between the First Restauration Period (1814) and the July Revolution (1830 $)^{11}$. The Doctrinaires' ideas on sovereignty and representation were subsequently projected back in time.

Even if, from a conceptual point of view, the Doctrinaires' understanding of representative government does not entirely coincide with Carré de Malberg's view, this finding has an important impact on the understanding of representative government in Belgium ${ }^{12}$. As the Belgian Revolution of 1830 erupted

$6 \quad$ Carré de Malberg, Contribution (supra, n. 1), vol. 2, p. 231 and p. 284.

$7 \quad$ Carré de Malberg, Contribution (supra, n. 1), vol. 2, p. 230.

8 Carré de Malberg, Contribution (supra, n. 1), vol. 2, p. 208-209.

9 Carré de Malberg, Contribution (supra, n. 1), vol. 2, p. 244-245 and p. 424-440.

10 G. Bacot, Carré de Malberg et l'origine de la distinction entre souveraineté du peuple et souveraineté nationale, Paris 1985; O. Bashkina, Raymond Carré de Malberg and the interpretation of sovereignty in the Belgian constitution, Giornale di Storia Costituzionale, 35 (2018/1), p. 149-166; P. Brunet, Les idées constitutionelles de Raymond Carré de Malberg (1861-1935), in: Le constitutionnalisme au xxe siècle, ed. by F. Julien-Laferrière and É. Millard, Brussels 2006, p. 1-32; M. Gauchet, La Révolution des pouvoirs, La souveraineté, le peuple et la représentation 1789-1799, Paris 1995; D. Mineur, De la souveraineté nationale à la volonté générale, L'évolution de Carré de Malberg, du projet positiviste au parti-pris démocratique, Jus Politicum, 8 (2012), p. 1-10; M. Troper, La constitution de l'an III ou la continuité, la souveraineté populaire sous la Convention, in: 1795, Pour une République sans Révolution, ed. by R. Dupuys and M. Morabito, Rennes 1996, p. 179-192.

11 The latter substituted the idea of a sovereignty based on a popular will with a sovereignty based on the transcendent principle of reason, justice and truth. For an in-depth study of the doctrinaire thought see especially A. Craiutu, Liberalism under siege, The political thought of the French Doctrinaires, Lanham 2003.

12 For the contrast between Carré de Malberg's understanding of the representative government and the doctrinaires' understanding, see J. Krulic, L'idée de peuple dans la 
amidst the development of the national sovereignty theory in France, questions arise regarding the soundness of the historical reading of the (intellectual) origins of Belgium's representative government. Did the Belgian founding fathers have knowledge of this national sovereignty theory and did they welcome it? Was the choice for representation generally accepted and did it necessarily entail the elections? Did representative government presuppose the existence of a will to be represented? Or did the representative bodies exclusively create the national will? Furthermore, to what extent were the representatives independent in the exercise of their 'representative mandate'?

In this article we address these questions by re-evaluating the representative system elaborated by the Belgian founding fathers between November 1830 and July 1831. The constituent debates in the National Congress will be our main source. When the constituent debates remain silent (as they do on certain aspects of the representative system, and almost completely on the understanding of sovereignty), we will turn to the press. The constituent debates were accompanied by a lively newspaper debate, which has proven a useful source for reconstructing the intellectual origins of the constitution ${ }^{13}$. Not only did close ties exist between congressmen and the press, the newspapers also reflected the ideological positions present within the National Congress ${ }^{14}$. Furthermore, as lawyers, jurists and former functionaries, many journalists were legally trained and well informed about political theory ${ }^{15}$.

For the purpose of this article, eight newspapers have been systematically analyzed between the outbreak of the Revolution in the end of August 1830

tradition constitutionnelle française, Sens Public, 2 (2007), p. 1-19; P. Rosanvallon, Les Doctrinaires et la question du gouvernement représentatif, in: The French Revolution and the creation of modern political culture, vol. 3, F. Furet and M. Ozouf edd., Oxford 1989, p. 411-431.

E.g. B. Deseure, National sovereignty in the Belgian constitution of 1831 , On the meaning(s) of Article 25, in: Reconsidering constitutional formation, ed. by U. Müßig, vol. 1, Berlin 2016, p. 93-156; E. Witte, Het natiebegrip in het Zuidelijk krantendiscours aan de vooravond van de Belgische opstand (augustus 1829-juni 1830), in: Bijdragen en Mededelingen tot de Geschiedenis der Nederlanden, 121 (2006/2), p. 222-236.

14 For an overview of the oppositional newspapers in Brussels: A.J. Vermeersch, Ontstaan, personele en structurele ontwikkeling van de Brusselse opiniepers en haar verhouding tot de regering van het Verenigde Koninkrijk der Nederlanden, 1814-1830, unpubl. doct. thesis, History, University of Ghent, Ghent 1981 .

$65 \%$ of the revolutionary leadership was composed of publicists, journalists and jurists. Half of the constituent assembly was composed of jurists: M. Magits, De socio-politieke samenstelling van de Volksraad (10 november 1830-21 juli 1831), Belgisch Tijdschrift voor Nieuwste Geschiedenis, 12 (1981/3), p. 583-589, 602; E. Witte, Changes in the Belgian Elite in 1830, A Provisional Study, in: The Low Countries History Yearbook, Acta Historiae Neerlandicae, vol. 13, Den Haag 1980, p. 109. 
and the inauguration of Leopold I on 21 July 1831, while others have been read fragmentarily. Their ideological profiles cover the whole range of political positions present at the time. The leading political newspapers and veterans of the liberal opposition against William I were the Liège based Le Politique and the Brussels based Courrier des Pays-Bas (shortened to Le Courrier from 1 January $1831 \mathrm{on})$. Their moderate, liberal agenda was mostly in tune with the majority opinion at the National Congress, with Le Courrier being the more progressive one of the two. Also in the center was L'Union belge, which served as official newspaper. To the left of these were the radical democratic and republican journals: the Brussels based L'Émancipation and Le Belge and the Namur based Courrier de la Sambre. L'Émancipation was the most radical daily, serving as the mouthpiece of the political club Réunion centrale, which was very influential in the early revolution ${ }^{16}$. Progressive Catholicism was represented by the Ghent based Journal des Flanders, which embraced modern constitutionalism out of a pragmatic concern to safeguard the position of the Church. To the far right of the political spectrum was the Courrier de la Meuse, representing the ultramontane and reactionary Catholicism which was popular especially with parts of the Belgian nobility. It goes without saying that political debate at the time was an elitist affair, reserved almost exclusively to a minority of educated and propertied citizens.

In the first section we will introduce the conception of sovereignty and its relation to the representative principle. We maintain that representation, to which the founding fathers almost unanimously adhered, was based on popular sovereignty. In this respect, their understanding of (represented) sovereignty fundamentally deviated from the theory of national sovereignty. In the second section we will argue that, by making representation 'national', the founding fathers subscribed to an understanding of representation that was close to, but not identical with, the modern understanding described above. This situation probably explains why Belgian doctrine later resorted to Carré de Malberg's analysis of the 1791 understanding of represented sovereignty. We will examine the scope of the representative mandate and question whether representation necessarily entailed elections. In the last section we will argue that the founding fathers also aimed to make the representative institutions 'genuinely' national. The representative institutions were embedded within a specific framework that allowed for participation and permanent contestation by the public opinion. This points at a reflexive relation between the legal

16 For the Belgian radicals, see E. Witte, Belgische republikeinen, Radicalen tussen twee revoluties (1830-1850), Antwerp 2020. 
order and the public sphere, an aspect which has largely been overlooked by the Belgian doctrine and which we aim to foreground again with this publication.

In 1815, after the disintegration of the Napoleonic Empire, the Southern Netherlands were joined with the Northern Netherlands into the United Kingdom under the rule of king William I of Orange-Nassau. From the 1820's on, dissatisfaction arose in the South, revolving around issues of religious, linguistic, educational and economic policy ${ }^{17}$. Around the end of the 1820's the built-up tension culminated in an open confrontation between the Southern opposition on the one hand and William I's government on the other. Central to the parliamentary trial of strength was the interpretation of sovereignty laid down in the Fundamental Law. Whereas William claimed that his royal sovereignty preceded the constitution, the opposition argued for the existence of national sovereignty and ministerial responsibility ${ }^{18}$. By the late summer of 1830 the authoritarian government response to the Southern discontentment, in combination with hunger riots, led to a full-blown revolution. The king's personal involvement in the conflict, and the shedding of civilian blood at the hand of government troops, brought about charges of despotism. These, in turn, contributed to undermining the legitimacy of the Orange-Nassau dynasty in the eyes of the Southern public opinion. On October 4th, 1830 a Provisional Government proclaimed the independence of the new Belgian state ${ }^{19}$. It instated a Constitutional Commission to draft a new constitution. A constituent

17 See e.g. N. Bijleveld, Van eendracht en partijzucht, De kerkpolitiek van koning Willem I, in: Het (on)Verenigd Koninkrijk, 1815-1830>2015, Een politiek experiment in de Lage Landen, ed. by R. Aerts and G. Deneckere, Rekkem 2015, p. 173-181; A. De Jonghe, De taalpolitiekvan koning Willem I in de Zuidelijke Nederlanden (1814-1830), De genesis der taalbesluiten en hun toepassing, Sint-Andries-Brugge 1967; R. Vosters and G. Janssens, Willems taalpolitiek, in: Het (on)Verenigd Koninkrijk, 1815-183o>2015, p. 153-162; S. Van de Perre, L'union de principe exige l'union des moyens, Economie, fiscaliteit en de (des)integratie, in: Het (on)Verenigd Koninkrijk, 1815-1830>2015, p. 163-170.

18 B. Deseure, Constitutional precedence and the genesis of the Belgian constitution of 1831 , in: Ulrike Müßig (ed.), Reconsidering constitutional formation, II: Decisive constitutional normativity, From old liberties to new precedence, Berlin 2018, p. 211-256; J. Koch, Le Roi décide seul / de Koning alleen besluit, Het 'systeem Willem I', in: Het (on)Verenigd Koninkrijk, 1815-1830>2015, p. 49-58; P. Van Velzen, De ongekende ministeriële verantwoordelijkheid, Theorie en praktijk 1813-1840, Nijmegen 2005.

19 Decree of 4 October 1830, Bull. Arr, n. 4, p. 9. 
National Congress was subsequently elected in order to discuss the draft and to draw up the definitive constitution ${ }^{20}$.

The Belgian Revolution resulted from a curious compromise between the two major competing ideologies in Belgian society at the time: Catholicism and liberalism. They found each other in a desire to prevent a future return to despotic rule, resulting in the constitutional limitation of royal power and extensive guarantees for personal liberty. The ideological spectrum within both movements was wide, ranging from ultraconservative to radical. Extreme positions were hardly represented in the National Congress however, nor was the sizeable minority of orangists, who remained loyal to the deposed dynasty ${ }^{21}$. Moneyed bourgeoisie (among whom were many lawyers) and aristocracy dominated the assembly. The constitutional recipes they agreed upon were of a prudently liberal kind, deeply influenced by Montesquieu and Benjamin Constant $^{22}$. The consensus was made possible by the temporary convergence between the ideas of local liberal theorists, such as Pierre-François Van Meenen, and those of progressive or 'transingent' Catholics ${ }^{23}$. Like all revolutionaries and political theorists of the Restoration age, the Belgian founding fathers sought a middle way between the monarchical principle and popular sovereignty ${ }^{24}$. William I's personal style of government had instated a clear wish in the Belgian opposition for the constitutional containment of the royal prerogative. But the idea of tyrannical rule by the people, exemplified by the 1793 Terror, was as daunting as royal despotism. The National Congress compromised between both extremes by designating the nation as the source of all the powers of the state (old art. 25 , first paragraph), while simultaneously making sure that the exercise of state power was constitutionally limited (old art. 25 , second paragraph $)^{25}$.

$20 \quad$ Decree of 11 November 183o, Bull. Arr. Gouv. Prov, n. 7, p. 5-9.

21 See E. Witte, Het verloren koninkrijk, Het harde verzet van de Belgische orangisten tegen de revolutie 1828-1850, Antwerp 2014.

22 A. De Dijn, A pragmatic conservatism, Montesquieu and the framing of the Belgian constitution (1830-1831), History of European Ideas, 28 (2002/4), p. 227-245; R. Geenens and S. Sottiaux, Sovereignty and direct democracy, Lessons from Constant and the Belgian constitution, European Constitutional Law Review, 11 (2015), p. 293-320.

23 See extensively: S. Marteel, The intellectual origins of the Belgian Revolution, Political thought and disunity in the Kingdom of the Netherlands, 1815-1830, Cham 2019.

24 B. Mirkine-Guetzevitch, Mille huit cent trente dans l'évolution constitutionnelle de l'Europe, Revue d'Histoire Moderne et Contemporaine, 6 (1931), p. 241-256; U. Müßig, L'ouverture du mouvement constitutionnel après 1830 , à la recherche d'un équilibre entre la souveraineté monarchique et la souveraineté populaire, Tijdschrift voor Rechtsgeschiedenis, 129 (2011), p. 489-519; M.J. Prutsch, Constitutionalism in post-1814 Europe, Monarchy, parliament and sovereignty, Journal of Constitutional History, 35 (2018), p. 33-46.

25 Deseure, National Sovereignty (supra, n. 13); H. De Smaele, Omdat we uwe vrienden zijn, religie en partijidentificatie, 1884-1914, unpubl. doct. thesis, History, KU Leuven, Leuven 
The classical understanding of national sovereignty defines the nation as an abstract, holistic entity. We have shown elsewhere that this understanding was not present in the Belgian constituent debates. Although the congressmen did prefer the term 'nation' over people, they did not understand the nation as a mere juridical abstraction. Instead, they saw it as a natural, empirically tangible and collective being with a deliberate wish for liberty ${ }^{26}$. The nation was not only sovereign in the formal sense but was truly to govern itself. In order to do so, a form of collective agency was needed, a way for the nation to formulate its wishes and to act accordingly ${ }^{27}$. Importantly, representation implied that the nation delegated the exercise, but not the source, of authority. A similar mechanism had already been instated under the French Directory. The idea that sovereignty needed to correlate with its exercise was replaced by a 'sovereignty of origin', where the people was not supposed to 'make the law', but still constituted the source of all juridical competences of the state ${ }^{28}$.

In order to operationalise the exercise of sovereignty, the Belgian founding fathers advocated a representative government that expressed the national wish in a continuous way, providing for reason, justice and liberty ${ }^{29}$. For many congressmen, a representative system based on 'direct and popular' elections was a conditio sine qua non for the new legal order ${ }^{30}$. The people's direct participation in public affairs (known from the republics of Antiquity) had

2002, p. 29-31; Geenens and Sottiaux, Sovereignty and direct democracy (supra, n. 22).

26 B. Deseure and C. Maes, 'All the Powers Emanate From the Nation'. People, Nation and Sovereignty in the Belgian Constitution of 1831, in: The People versus the Nation. Sovereignty, Civic Participation, and Constitutional Law in Belgium, ed. by B. Deseure, R. Geenens, and S. Sottiaux, Abingdon \& New York (in press). Deseure, National sovereignty (supra, n. 13), p. 93-156.

$27 \quad$ For the Belgian conception of representative collective agency, based on the social groups in the state, see A. de Dijn, De afweging van het algemeen belang, Politiek en economie in het negentiende-eeuwse België, in: Politieke representatie, ed. by J. Tollebeek and H. De Smaele, Leuven 2002, p. 249-253; S. Marteel, Polemieken over natievorming in het Verenigd Koninkrijk der Nederlanden, Een blik op de intellectuele wortels van het Belgisch nationalisme, in: Taal, cultuurbeleid en natievorming onder Willem I, ed. by R. Vosters and J. Weijermars, Brussels 2011, p. 35-59.

28 Krulic, L'idée de peuple (supra, n. 12), p. 14.

29 The congressmen do not seem to have clearly distinguished between national 'will', 'wish' or 'interest'. We argue that the term national wish - which attributes a certain latitude in the representatives' decisional autonomy, without entirely dissociating the link between their decisions and the will of their constituents - more accurately expresses the founding fathers' view than the 'national will'. On the origin of the distinction, see H. Grange, Les idées de Necker, Paris 1974, p. 267-272.

30 C. Maes, The end justifies the means, The nature of Belgium's 1830 political liberalism, Journal of Constitutional History, 35 (2018), p. 129-145. 
become obsolete in the modern age. The congressmen agreed that, in modern times, delegation of power and representative institutions were key ${ }^{31}$. Even the radical and republican members admitted that no state system was feasible without representation ${ }^{32}$.

Whereas explicit discussion of sovereignty remained limited in Congress, the newspapers debated the issue headlong. With the exception of a few newspapers on the far left and the far right of the political spectrum, a large majority subscribed to the principles of popular sovereignty and representation ${ }^{33}$. All agreed that sovereignty emanated from below, but that immediate agency of the national wish, associated with demagogy, social troubles and the decline of the nation, was to be avoided. Hence the need to delegate the exercise of sovereignty to the different constituted powers. This did not mean that the nation surrendered its inalienable sovereignty ${ }^{34}$, as the radical liberal papers especially were eager to stress ${ }^{35}$.

The influential moderate liberal newspaper Courrier des Pays-Bas characterised representation in striking terms:

[...] deux êtres qui n'étaient au fond que le même, sous deux modes différens [sic] d'existence: la nation, c'est-à-dire, tout le peuple; et la représentation nationale, c'est-à-dire, le peuple encore, mais agissant sous une forme convenue, pour faciliter à lui-même l'exercice de la volontés ${ }^{36}$.

This conception of representation clearly indicates an organic identification between the people and its representatives. Yet, at the same time, it also shows that this identification was not complete: representation facilitated the exercise of the will. In other words, it was a means to channel the nation's will,

$31 \quad$ E. Huyttens, Discussions du Congrès National de Belgique 1830-1831, vol. 1, Brussels 1844, p. 198, 19/11/1830, Destriveaux; ibid, p. 212, 20/11/183o, Devaux; Huyttens, Discussions, vol. 2, p. 28, o6/o1/1831, Defacqz.

32 Huyttens, Discussions (supra, n. 31), vol. 1, p. 249-250, 22/11/183o, Goffint; ibid, p. 197, 22/11/183o, Lardinois; ibid, p. 196-197, 19/11/183o, Seron; ibid, p. 253, 22/11/183o, Seron; ibid, p. 228, 20/11/183o, de Robaulx.

33 Deseure and Maes, 'All the Powers Emanate From the Nation' (supra, n. 26).

34 Le Belge, o3/10/1829, n. 276, Où réside la souveraineté?.

35 Deseure and Maes, 'All the Powers Emanate from the Nation' (supra, n. 26).

36 ' [...] two beings which were essentially the same, under two different forms of existence: the nation, in other words the people; and the national representation, in other words, the people again, but acting in an agreed-upon form, to facilitate the exercise of its will': Courrier des Pays-Bas, 17/11/1830, n. 321, Sur la démission de M. De Potter. 
thereby effectively constituting the nation internally ${ }^{37}$. Although the people continued to be the original holder of sovereign power, it delegated the execution to its ordinary (legislative assembly) or extraordinary (National Congress) representatives. In principle, the nation could directly intervene in its affairs, but from a practical and normative point of view this was undesirable.

In short, we can conclude that the founding fathers recognised the principle of popular sovereignty and that most of them understood it to imply the principle of representation. By contrast, the national sovereignty doctrine, as later formulated by Carré de Malberg, did not inform their deliberations.

\section{A 'national' representation}

According to the Belgian revolutionaries, William I's rule had been a corruption of the representative principle ${ }^{38}$. His government had no political responsibility towards the representative Chambers ${ }^{39}$, whereas the elections were being manipulated by the government $t^{40}$. In addition, William I's administration worked in an untransparent manner which did not allow for public control. The new institutions of the Belgian state were conceived as a true national representation, based on the liberal ideals of liberty and political equality. In order for representation to be national, social orders and privileges were eliminated, and every citizen (theoretically) obtained access to public functions. However, the exclusion of corporate interests and social orders necessitated a redefinition of representation. In this, the Belgian founding fathers have been influenced by the modern understanding of representation inherent to the French Constitution of 1791 and subsequently elaborated by French

37 'Les Belges, affranchis de l'odieuse domination des Nassau, se sont constitués en corps de nation' ('The Belgians, freed from the odious domination of the Nassau's, have constituted themselves as a nation'): Huyttens, Discussions (supra, n. 31), vol. 2, p. 138, 13/o1/1831, Masbourg. In a letter to the Courrier des Pays-Bas, Lebeau asserted that the country was internally constituted since the moment of the election of the Congress as national representation: letter of Lebeau of May 14th, 1831, published in Courrier des Pays-Bas, 16/05/1831, n. 136.

38 Lebeau spoke of a 'système bâtard de gouvernement représentatif': Huyttens, Discussions (supra, n. 31), vol. 1, p. 518, 16/12/183o, Lebeau. See also Huyttens, Discussions (supra, n. 31), vol. 1, p. 661, 27/12/183o, Le Hon. Le Belge and Le Politique spoke of a 'denaturation' of the constitutional regime. Le Belge, 29/11/1829, n. 333; Le Politique, 10/o2/1831, n. 35 . Koch, Le Roi décide seul (supra, n. 18), p. 49-58; Van Velzen, De ongekende ministeriële verantwoordelijkheid (supra, n. 18).

40 For a critical view of these manipulations, see N.C.F. Van Sas, De metamorfose van Nederland, Van oude orde naar moderniteit 1750-1900, Amsterdam 2005, p. 414 with fn. 3. 
doctrinaire thinkers ${ }^{41}$. As we will show, a number of important differences existed nevertheless.

Legal scholars and historians have argued that the 1791 Constitution disconnected the representative function from elections ${ }^{42}$. This meant that it was no longer a matter of knowing 'who' was to be represented (individuals, social groups, professions, etc.), but rather 'what' was to be represented (the common good or interests) ${ }^{43}$. The essential criterion thus became the selection procedure that guaranteed that representatives would act in conformity with the national interests. The modality of appointment of the representatives (elections) consequently became less important than the function of the representatives (discerning the national interests and acting or deciding accordingly). Deputies were national representatives because they represented the national interests, not necessarily because they were elected ${ }^{44}$. This 'virtual representation' was further established with the abolition of the imperative mandate, which had previously tied the representatives to the (often divergent) instructions of their constituents, thus impeding the political unification of the nation. The elimination of binding instructions from the electorate enabled the representatives to grasp the general interest via mutual deliberation and, in turn, to speak for the collective ${ }^{45}$. Through this representative action the nation was politically constituted and gained its juridical personality.

In Belgium, such a conception of representation already circulated at least a decade prior to the 1830 Revolution. In 1819, the important liberal newspaper L'Observateur Belge cited Pierre Daunou's Essai sur les garanties individuelles que réclame l'état actuel de la société $(1819)^{46}$. The newspaper endorsed

41 P. Foriers, Le droit investi par la politique, in: Dialogues multiples, Hommage à Paul Foriers, Brussels 1981, p.16-17; J. Velu, Vertegenwoordiging en rechterlijke macht (eerste deel), Rechtskundig Weekblad, 18 (1997), p. 599-6oo.

A. Alen, Rechter en bestuur in het Belgische publiekrecht, de grondslagen van de rechterlijke wettigheidskontrole, vol. 2, Antwerp 1984, p. 482-484; Bacot, Carré de Malberg (supra, n. 10), p. 85-87; P. Brunet, La représentation, in: Traité international de droit constitutionnel, ed. by M. Troper and D. Chagnollaud, vol. 1, Paris 2012, p. 625-631; Rosanvallon, Les Doctrinaires (supra, n. 12), p. 415-416; Velu, Vertegenwoordiging (supra, n. 41), p. 600.

43 The distinction already appeared during the American Revolution in the debates between the Federalists and Anti-Federalists. Brunet, La représentation (supra, n. 42), p. 625-627.

44 P. Gueniffey, Le Nombre et la Raison, La Révolution française et les élections, Paris 1993, p. 17; Rosanvallon, Les Doctrinaires (supra, n. 12), p. 415-420.

45 Thus, the abolition of the imperative mandate had a practical purpose and was not the direct or mechanical consequence of the 'choice for a one and indivisible sovereignty of the nation': Brunet, La représentation (supra, n. 42), p. 628; Troper, La constitution de l'an III (supra, n. 10), p. 179-192.

46 Pierre Daunou, a former Girondin who played an important political role under the Directory, Napoleon and the Restauration period, was a member of the liberal group of 
Daunou's point of view that representatives were supposed to be 'tellement désignés ou choisis, qu'ils [les représentants] aient, en effet, par eux-mêmes et de leur propre fond, les intérêts, les opinions, les volontés des représentés'47. It followed that, despite being unelected, provincial representative assemblies, the hereditary assembly, the monarch, the jury, and even the electorate could represent the nation alongside the national representative assembly ${ }^{48}$.

The dissociation of representation from the elective principle reappeared in the $183^{1}$ constitutional edifice ${ }^{49}$. Unquestionably, elections were by far preferred over heredity or divine origin as the essential legitimating principle on which the formation and the working of public authority hinged ${ }^{50}$. In addition, elections provided for a procedure of selection and even purification, while symbolizing at the same time the idea of consent to power, equality and participation ${ }^{51}$. They also generated in the electorate a sense of obligation and commitment towards the elected office holders. From the point of view of the represented, elections had the advantage of limiting the representatives' power to their term of office ${ }^{52}$. For all these reasons, the choice for elections seemed almost self-evident to the founding fathers, who mainly aimed at substituting the 'cascade-system' of indirect elections under the United Kingdom of the Netherlands, in which provincial representatives elected the national

the Idéologues. He was closely associated to Benjamin Constant, with whom he entered the Tribunate under Napoleon. Joseph Lebeau was the first to publish Daunou's Essai in Belgium in 1827 .

47 ' [...] designated or chosen in such a way that they would have by themselves and within themselves the interests, the opinions, the wills of the represented': D'Elhoungne, Doncker and Van Meenen, L'Observateur politique, administratif, historique et littéraire de la Belgique par une société de jurisconsultes et d'hommes de lettres, vol. 18, Brussels 1819, p. 407.

$48 \quad$ Ibid, p. 407-408.

49 Old articles 47 and 53 of the Constitution.

50 The Congress voted with great majority for an elected senate (130 votes against 40 ). The Congress even considered the 'election' of the monarch as a crucial legitimating factor: 'Qu'il soit notre roi, non par la seule grâce de Dieu, [...] mais par l'élection des représentants d'une nation qui a su conquérir son indépendance' ('That he may be our king, not merely by the grace of God [...] but by the election of the representatives of a nation that has conquered its independence'): Huyttens, Discussions (supra, n. 31), vol. 2, p, 301, 29/o1/1831, de Langhe.

$51 \quad$ Rosanvallon, Les Doctrinaires (supra, n. 12), p. 417.

$5^{2}$ On the various functions of elections see B. Manin, The principles of representative government, Cambridge 1997. For the Belgian case see A.-E. Bourgaux, La démocratisation du gouvernement représentatif en Belgique, une promesse oubliée, vol. 1, unpubl. doct. thesis, Law, Université Libre de Bruxelles, Brussels 2013, p. 214-220. 
representatives, for a 'fair' and direct electoral system ${ }^{53}$. In the words of liberal congressman Defacqz: 'En consacrant l'élection directe, on est revenu au bon système, à celui qui seul peut donner à la nation de vrais représentants, et on a proscrit pour jamais le système d'élection à ricochets, adopté par l'ancien gouvernement ${ }^{54}$. A cascade system only concentrated power in the hands of the few, discarding the true nation's true wish ${ }^{55}$, and it weakened the representative link between the electorate - 'le fond de la nation'56 - and the representatives ${ }^{57}$. The congressmen, in contrast, grounded their representative system on directly elected legislative assemblies, expected to act in accordance with the national interest ${ }^{58}$. Congressman Charles Le Hon could not have voiced this idea more strongly, when he stated that 'la source de tous les pouvoirs réside dans les élections'59.

53 See in this regard especially the discussion on the nomination of the senators. Huyttens, Discussions (supra, n. 31), vol. 1, p. 508-523, session of 16/12/1830.

54 'By consecrating direct elections, we have come back to the true system [...], the only system that can give true representatives to the nation': Huyttens, Discussions (supra, n. 31), vol. 2, p. 28, o6/o1/1831, Defacqz.

55 J. Lebeau, Observations sur le Pouvoir Royal ou Examen de quelques questions relatives aux droits de la couronne dans les Pays-Bas, Liège 1830, p. 70.

56 Courrier des Pays-Bas, o2/og/183o, n. 245.

57 The former indirect electoral system was based on the principle 'which made the powers emanate from each other' ('tous les pouvoirs émanent les uns des autres'), whereas the new system provided in art. 25 that all powers emanated (directly) from the nation: $\mathrm{x}$, Handelingen van de regering en de Staten-Generaal over de herziening der Grondwet, vol. 4, s'Gravenhage 1842, p. 437-439. See Courrier des Pays-Bas, 04/o9/1830, n. 247. See also Bourgaux, La démocratisation (supra, n. 52), p. 307 with fn. 1412. French doctrinaire thought, on the other hand, repudiated indirect elections for a different reason, namely the non-transferability of electoral capacity from a secondary electorate to a primary one. J. Roels, La théorie doctrinaire du régime représentatif, les discours parlementaires de RoyerCollard, Parliaments, Estates and Representation, 2 (1982/2), p. 163-164.

58 Consequently, Van Meenen believed that 'the nation should be heard' each time a decision was to be taken that affected the national interest ('la nation doit être entendue chaque fois qu'il s'agit de son intérêt'). Hence the need for approval of the legislative chambers on commercial treaties that affected the State or the Belgian citizens: Huyttens, Discussions (supra, n. 31), vol. 2, p. 77, 10/o1/1831, Van Meenen. The principle of direct elections for the senators was discussed during the sessions of 16 and 17 December 1830. The direct election of the members of the Chamber were discussed on 6 January 1831 . Resp. Huyttens, Discussions (supra, n. 31), vol. 1, p. 502-542; Huyttens, Discussions (supra, n. 31), vol. 2, p. 27-3o. For the discussions in sections see Huyttens, Discussions du Congrès National de Belgique 1830-1831, vol. 4, Brussels 1844, p. 72-74, pièce just. n. 54, report Raikem of 24/12/183o; ibid, p. $75-82$, pièces just. n. $55-56$, reports Devaux of $04 / 12 / 183$ o and $11 / 12 / 1830$.

59 Huyttens, Discussions (supra, n. 31), vol. 2, p. 29, o6/o1/1831, Le Hon. See also Huyttens, Discussions (supra, n. 31), vol. 1, p. 208, 20/11/183o, Lebeau: 'le principe de l'élection domine tout; qu'il influe non-seulement sur la marche de l'administration intérieure et extérieure, 
But although elections were direct and representation was characterised as 'national', suffrage was far from universal. Census suffrage enfranchised less than $1 \%$ of the population. The governing representatives in the Chambers could not claim to be representing the nation on the basis of their election, as only a slight fraction of the population had participation in it. If sovereignty had exclusively depended on elections, the congressmen should have opted for universal suffrage instead of a census-based suffrage. In this regard, the electors themselves exercised a representative function, since they were supposed to speak for the nation at large when electing national representatives ${ }^{60}$.

The very exclusive version of censitary suffrage forwarded by the moderate liberal and Catholic deputies was criticised on the far left and right side, although for different reasons. The left-wing radicals denounced the Provisional Government - which had organised the constituent elections - for having excluded the part of the population which had most actively engaged in the revolution ${ }^{61}$. Republican congressman de Robaulx virulently attacked the advocates of a high census restriction, accusing them of intentionally substituting the people's will with their own ${ }^{62}$. Radicals like de Robaulx firmly rejected the idea that the electorate exercised a function. They believed that the constitutional principle of equality before the law also entailed social equality ${ }^{63}$. Hence, they considered representative agency as the exercise of a collective right of the nation. Accordingly, the relation between the representatives and their constituents was of a contractual nature ${ }^{64}$.

Nevertheless, none of the radicals advocated universal suffrage. They considered suffrage restrictions a necessary evil that made representation

mais qu'en outre, il exerce sur la composition du pouvoir exécutif une irrésistible influence' ('the elective principle dominates everything; not only does it command the functioning of the internal and external administration, but it also guides the composition of the executive power').

6o 'Les radicaux sont en erreur quand ils font un droit de ce qui n'est qu'une fonction. C'est le corps social représenté par nous qui doit déterminer les qualités requises pour les fonctions électorales' ('The radicals are wrong to transform a mere function into a right. It is the social body, which we represent, that has to determine the required qualities for the electoral functions'): Huyttens, Discussions (supra, n. 31), vol. 2, p. 532-533, 16/o2/1831, Van Meenen.

61 Huyttens, Discussions (supra, n. 31), vol. 2, p. 532, 16/o2/1831, A. Rodenbach. See also L'Émancipation, 30/10/1830, n. 10.

62 Huyttens, Discussions (supra, n. 31), vol. 2, p. 640, o2/o3/1831, de Robaulx.

63 Huyttens, Discussions (supra, n. 31), vol. 2, p. 533, 16/o2/1831, de Robaulx.

64 Ibid. Bourgaux has deduced from these and other interventions in Congress, as well as from former political practice in Belgium, that the congressmen generally understood their representative function in a contractual fashion, resulting in an ambiguous representative link: Bourgaux, La démocratisation (supra, n. 52), p. 293-320. 
effective and enabled the expression of the national wish in practice. Consequently, the limitation of suffrage in itself was considered legitimate, on the condition of being liberal enough so as to include a substantial part of the population ${ }^{65}$.

On the other side of the political spectrum, the Catholic, conservative newspaper Courrier de la Meuse used the franchise restrictions to argue against popular sovereignty. It refuted any direct connection between the popular will and the representatives by claiming that the National Congress represented not the whole people but only the electoral colleges, which in the end consisted only of an infinite fraction of the population ${ }^{66}$. Hence, the newspaper argued, by restricting suffrage to the rich, the National Congress violated its own principle of popular sovereignty. Since the people was very badly represented in Congress ${ }^{67}$, the majority of the nation remained excluded from sovereignty ${ }^{68}$. Ultimate power was not wielded by the people, but only by a specific group of propertied representatives ${ }^{69}$. Since the Constitution had instituted a 'kind of democracy', the representatives were the ones in power now.

The Courrier de la Meuse stood alone with this point of view. Only the enlightened social elite was called upon to represent the nation, but most revolutionaries expected that, by concentrating the intellectual elite in government, they could be sure that government would act in accordance to the will of Belgian society as a whole ${ }^{70}$. Currently, intelligence was unevenly dispersed over

65 Huyttens, Discussions (supra, n. 31), vol. 2, p. 533, 16/o2/1831, de Robaulx. At the same time, the republicans maintained that the representative institutions should concentrate the most enlightened and virtuous citizens in their midst. E.g. congressman Lardinois rejoiced over the fact that the Congress was 'composé de l'élite de la nation, qu'il est plein de lumières, d'intentions pures et de vues de bien public' ('composed of the elite of the nation, that it is filled with enlightenment, pure intentions and insight in the public good'): ibid, p. 91, 11/o1/1831, Lardinois. For de Robaulx, see the closing words in his plea for a republic: 'Je vote pour la république, parce qu'elle est le triomphe des capacités et de la vertu' ('I vote for the republic, because it is the triumph of capacity and of virtue'): Huyttens, Discussions (supra, n. 31), vol. 1, p. 255, 22/11/1830, de Robaulx.

66 Courrier de la Meuse, o7/11/183o, n. 269; Courrier de la Meuse, o9/12/183o, n. 296.

67 Courrier de la Meuse, 12/11/1830, n. 272.

68 Courrier de la Meuse, 3o/12/183o, n. 314.

69 Courrier de la Meuse, o3/o3/1831, n. 53.

70 'Les gouvernements appartiennent aux capacités, aux intelligences' ('Governments belong to capacity, to intelligence'): Huyttens, Discussions (supra, n. 31), vol. 1, p. 263, 23/11/183o, C. Rodenbach: 'c'est dans la législature que vous trouverez les hautes capacités' ('it is within the legislative power that you will find the best capacity'): ibid, p. 702, 29/12/1830, C. de Brouckère: 'Le gouvernement représentatif est le gouvernement des capacités. Il faut les prendre partout où on les trouve' ('The representative government is the government of capacity. One must take it wherever one finds it'): ibid, p. 7oo, 29/12/1830, Lebeau. 
the nation ${ }^{71}$. Hence, not everyone had the capacity to participate in public affairs. Financial and moral independence, and a certain degree of enlightenment, were deemed indispensable in order to accurately represent the nation's interests ${ }^{72}$. The discrimination between voters and non-voters was not written in stone, however. Leading liberal publicist and founding father Joseph Lebeau asserted that the more society advanced, the more the census would be low$\operatorname{ered}^{73}$. Ideally, the congressmen believed, society would advance to a point where suffrage restrictions would be abolished ${ }^{74}$.

Old article 32 of the Constitution provides another indicator of the congressmen' modern understanding of national representation (i.e. detached from elections). The article states that 'The members of the two Chambers represent the nation, and not just the province or the subdivision of the province which appointed them', which implies the rejection of the imperative mandate $^{75}$. Congressman Lucien Jottrand was more explicit on this point in the discussion over the exclusion of the Orange-Nassau family from dynastic succession in Belgium. His colleague Alexandre Rodenbach claimed that the dynasty's exclusion was the people's will. According to Rodenbach, this popular will 'exploded' from everywhere. Not only had it erupted by means of a popular revolt against William; now that the issue of dynastic exclusion was discussed in Congress, the popular will flared up again through the agitation in newspapers, in political clubs and on the streets. The congressmen were compelled to sanction the people's decision of exclusion, not doing so was to put their legitimacy as representatives at stake ${ }^{76}$. Jottrand, and the majority of the Con-

71 The discussion on the uneven distribution of intelligence and capacity among the population confirms that the Belgian founding fathers conceived the nation as a heterogeneous, hierarchical entity, in contrast to Carré de Malberg's understanding. 'C'est la propriété qui est le fondement du cens ; c'est le payement du cens qui intéresse à la prospérité du pays : il faut donc payer ce cens pour exercer le droit le plus précieux de citoyen' ('Property is the basis of the census; the payment of the census concerns the prosperity of the country: the census must be paid in order to exercise the citizen's most precious right'): Huyttens, Discussions (supra, n. 31), vol. 2, p. 30, o6/o1/1831, Le Hon.

73 Ibid, p. 535, 17/02/1831, Lebeau. It was generally recognised that many aspects of the governmental form were to be built upon principles that were accommodated to the 'needs of the era': Huyttens, Discussions (supra, n. 31), vol. 1, p. 192, 19/11/183o, Nothomb.

'[...] le jour viendra où les masses populaires seront assez éclairées pour concourir, sans aucune exception, et sans danger, à l'élection des députés' ('[...] the day will come when the popular masses will be enlightened enough to participate, without any exception, and without danger, to the election of the representatives'): Courrier des Pays-Bas, 28/04/1831, n. 118.

75 Actual art. 42 .

76 Huyttens, Discussions (supra, n. 31), vol. 1, p. 268, 23/11/1830, Rodenbach. See in the same sense Ibid, p. 282, 23/11/183o, de Haerne. 
gress with him, rejected this view on the representative mandate. According to Jottrand, the representatives could not refer to the interpretation of the 'people's will' put forward by Rodenbach, as this was merely a subjective appreciation of a passionate expression of opinion which might be subject to errors of judgement. The representatives - taken from the most intelligent amongst the people and continuously deliberating in conformity with the national interests - were the ones expressing the 'real' popular will. Although Jottrand admitted that in this specific case the 'external opinion' was right to proclaim itself hostile against the Orange-Nassau family, he rejected interference in the representative work of the Congress ${ }^{77}$. One day later, Catholic leader Etienne de Gerlache used the same argument to argue against the exclusion: 'Le peuple a trop de confiance dans ses défenseurs naturels pour vouloir substituer une volonté aveugle à la raison et à leur expérience ${ }^{78}$.

Finally, the idea that representation did not presuppose elections distinctly surfaced in the congressional debates regarding the role of the monarch. A large majority of congressmen endorsed a model of mixed government, combining the elective (legislative Chambers) with the hereditary principle (monarch) in the legislative decision-making process (old art. 26). In the case of the French Constitution of 1791, the Constituante had refused to admit the king as a co-legislator. Gradually and out of conceptual necessity, the French revolutionaries attributed a representative role to the King ${ }^{79}$. Yet, his participation in the legislative power and his representative function were explained in a mere mechanical fashion, entirely subordinate to the Corps Législatif. The

77 Huyttens, Discussions (supra, n. 31), vol. 1, p. 28o-281, 23/11/1830, Jottrand. See in the same sense especially Le Hon's inflamed intervention against the republican de Robaulx on January 7th, 1831. Ibid, p. 46-47, o7/o1/1831, Le Hon with reference to de Robaulx' speech, ibid, p. 45, 07/01/1831.

78 'The people trusts its natural protectors too much for substituting their reason and their experience for a blind will'. De Gerlache defines the representatives as 'natural' protectors, which stresses the equation of interests and the organic identification between representatives and the people: Huyttens, Discussions (supra, n. 31), vol. 1, p. 306-307, 24/11/183o, de Gerlache. One month later, Surlet the Chokier asserted that 'nous répondons de nos votes à notre conscience seule' ('we stand accountable for our votes to our conscience only'). Ibid, p. 639, 24/12/183o, Surlet de Chokier (Président).

79 In order to defend himself against the Corps Législatif, the monarch was attributed a place in the legislative power. Afterwards, when the question arose whether to attribute him veto-power, the only way to account for his place in the legislative power was to admit him as a representative. Note that Carré de Malberg's analysis does not admit a representative function for the monarch, which has been criticised in French legal scholarship: P. Brunet, La notion de représentation sous la Révolution française, Annales historiques de la Révolution française, 328 (2002), p. 41-45; Maulin, Carré de Malberg (supra, n. 2), p. 5-25. 
Belgian congressmen went further, by admitting the king as a genuine national representative who acted on the same representative level as the two other organs of the legislative branch (Chamber and Senate). Since the monarch disposed of the right of legislative initiative (old art. 27), the absolute legislative veto (old art. 69) and the right to disband the legislative chambers (old art. 71), he could effectively steer the national wish in a certain direction, when he believed that the representative chambers neglected their representative tasks:

En supposant que la lutte s'établisse entre les deux chambres, le chef de l'État la fera cesser dès qu'il le trouvera convenable, soit en prononçant la dissolution d'une chambre qui ne représenterait plus l'opinion du pays, soit en rompant la majorité d'un sénat assez aveugle pour demeurer rebelle aux vœux du pays ${ }^{80}$.

This view was shared by the majority of congressmen. Writing in the context of the Dutch representative system one year earlier, Lebeau had advanced that the monarch's position as national representative entailed a right of dissolution of the Chambers ${ }^{81}$. To this end, the monarch had 'le droit de savoir si l'opinion de la chambre est l'opinion des électeurs. Si la nation, représentée par les électeurs, pense comme ses députés, le roi doit céder'82. Clearly, Lebeau considered the monarch to be a national representative. At the same time, these passages in Lebeau's work indicate that the representatives did not have a monopoly on the creation of the national wish and that he did not dissociate the representatives from the electorate's wishes. The monarch, by examining the need for the parliament's dissolution, could indeed determine whether the

80 'In the hypothesis that a conflict emerges between the two Chambers, the Head of the State will end it the moment he finds it suitable, either by pronouncing the dissolution of a Chamber that is not representing the country's opinion anymore, or by breaking the majority of a Senate that is blind enough to remain in rebellion against the wishes of the country': Huyttens, Discussions (supra, n. 31), vol. 1, p. 397, 13/12/183o, De Baillet. Nothomb equally identified the right of dissolution as '[un] droit extrême d'en appeler au pays' ('an extreme right to call upon the country'). Van Meenen expressed a similar view, when he stated that the monarch could never use the right of dissolution against the "[le] vœu manifeste du pays' ('[the] manifest wish of the country'). Ibid, p. 425, 14/12/183o, Nothomb: ibid, 538, 17/12/183o, Van Meenen.

$81 \quad$ Lebeau, Observations (supra, n. 55), p. 65 and p. 67.

82 'the right to know whether the opinion of the chambers is the opinion of the voters. If the nation, represented by the voters, thinks like its representatives [députés], the king must yield': Lebeau, Observations (supra, n. 55), p. 65. 
wish of the electorate effectively corresponded with the position of the representatives. If that were the case, he had to give way to parliament ${ }^{83}$.

The radical democrats persistently opposed the idea of non-electoral representatives. They were convinced that political representation should find its legitimation exclusively in the elections and in the principle of indivisibility. Only elections could provide for a government based on the popular will. Positioning the monarch next to the people was highly problematic in the radical view $^{84}$. How could the indivisible sovereign people, personified by the elected representative body, possibly share its sovereign power with a hereditary monarch? The radical newspaper L'Émancipation wrote that, since all the powers emanated from the people, monarchical power was inimical to it ${ }^{85}$. Monarchs inevitably try to extend their power at the people's expense, their representing the nation was simply inconceivable. Monarchy and people were rivalling powers, whose conflict would lead to structural unrest and instability. In the same vein, the Courrier de la Sambre called the Congress' choice for monarchy, 'une ridicule transaction entre la légitimité et la souveraineté du peuple, entre le passé et le présent, en voulant concilier des choses essentiellement

83 Rodenbach affirmed that the monarch could only act as sovereign if he identified himself with the nation by taking the wishes of the people into account. De Muelenaere shared Rodenbach's mindset when he argued that the royal heir should automatically be made senator. Admitting the future monarch in the senate would not only get him acquainted with the national institutions, but it would inform him of 'les vrais intérêts du pays' ('the true interests of the nation'). See also Le Hon's intervention, where he argued for the establishement of a senate, 'sous la condition toutefois que [le sénat] soit constituée de manière à ce qu'en cas de résistance systématique ou hostile aux vœux ou aux intérêts nationaux, cette résistance puisse être légalement arrêtée ou vaincue' ('established in a fashion that, should there emerge a systematic or hostile resistance against the national wishes or interests, this resistance can be legally stopped or overcome'): Huyttens, Discussions du Congrès National de Belgique 1830-1831, vol. 3, Brussels 1844, p. 138, 25/05/1831, C. Rodenbach: Huyttens, Discussions (supra, n. 31), vol. 1, p. 549, 18/12/183o, de Muelenaere; ibid, p. 492, 15/12/1830, Le Hon.

84 Huyttens, Discussions (supra, n. 31), vol. 1, p. 216-217, 20/11/183o, de Haerne; ibid, p. 226, 20/11/183o, de Robaulx.

85 'nous nous sommes déclarés contre ces sortes de gouvernemens [sic], parce que le principe de l'hérédité est contraire à la souveraineté des peuples, seule puissance qu'on puisse aujourd'hui bien comprendre, et parce que ces deux principes tant qu'ils seront en présence, occasionneront des troubles et des guerres dont le peuple sera toujours la première victime' ('we have opposed those forms of government, because the principle of heredity goes against the peoples' sovereignty, the only power that we can understand today, and because these two principles, as long as they are in presence of each other, will generate troubles and wars of which the people will always be the first victim'): L'Émancipation, o9/11/1830, n. 3 o. 
inconciliables' 86 . The republicans' key belief was that representation should remain one and indivisible, a belief which they clearly manifested in Congress: 'l'unité sociale appelle, commande même l'unité de représentation ; une seule nation, une représentation unique pour délibérer les lois, un seul constitué pour en garantir l'exécution'87.

When the composition of the legislative power (old art. 26) was discussed in Congress, republican congressman Seron proposed to amend the article in the draft constitution (art. 2). The article provided the monarch with a legislative role, next to the legislative chambers. Seron argued that this would go against the content of the previously adopted art. 25 , stipulating that all powers emanate from the nation. Elected representatives were a necessary precondition for the expression of the national wish, but this consisted merely in a temporary delegation of sovereignty ${ }^{88}$. Hence, it would be absurd to integrate the principle of heredity in the legislative power: in his executive functions the monarch merely acted out the will of the elected representatives. Admitting the monarch to the legislative power would perpetually deprive the nation of its capacity to reclaim its indivisible sovereignty ${ }^{89}$.

Republican congressman de Robaulx came up with an even more clever argument ${ }^{90}$. Now that Congress had opted for monarchy, he maintained, it was confronted with the conceptual inconsistency of its choice: one of monarchy's main raisons d'être was to prevent political disturbances which might spring from the passions of the 'democratic Chamber'. Once this choice had become definite, many congressmen advanced that a moderating power in the form of a senate was needed in order to appease potential conflicts between the elected Chamber and the hereditary monarch. De Robaulx asserted that this reasoning was irreconcilable with the argument that the monarch functioned as a

86 '[...] by trying to reconcile two things that are, essentially, mutually exclusive, a ridiculous transaction between legitimacy and the sovereignty of the people, between the past and the present'. Le Courrier de la Sambre, 31/12/1830, n. 231.

87 ' [...] the social unity calls for, commands even, the unity of representation; one single nation, one unique representation to deliberate about the laws, one single entity to guarantee its execution'. Huyttens, Discussions (supra, n. 31), vol. 1, p. 493, 15/12/183o, J.-F. Gendebien. See also Huyttens, Discussions (supra, n. 31), vol. 1, p. 404, 13/12/183o, Van Snick; ibid, p. 431, 14/12/1830, Seron; ibid, p. 439-440, 14/12/183o, Fleussu. The argument of indivisibility was also used by moderate liberals who opposed bicameralism: ibid, p. 426, 14/12/1830, C. de Brouckère; ibid, p. 458-459, 14/12/1830, A. Rodenbach; ibid, p. 467, 14/12/1830, Baron d'Huart.

88 Huyttens, Discussions (supra, n. 31), vol. 2, p. 15, o3/o1/1831, Seron.

89 Ibid. See also, concerning the senate: Huyttens, Discussions (supra, n. 31), vol. 1, p. 216, 2o/11/183o, de Haerne; ibid, p. 453, 14/12/183o, Wannaar.

90 Huyttens, Discussions (supra, n. 31), vol. 1, p. 486-489, 15/12/183o, de Robaulx. 
representative of the nation ${ }^{91}$. As such, he could only hold on to the national interests, which were already represented by the Chamber. Consequently, if the people aimed to overthrow the monarch, it would be acting against a representative of the nation - and thus against its own will. Since the interests of both representative actors correlated, why create a third actor in order to defuse a problem that could (at least theoretically) not arise ${ }^{92}$ ? This issue entailed another problem, grounded in the representative function of the senate: on the one hand, de Robaulx explained, the senate might represent interests which were separate from the nation's interests. He ironically argued that his colleagues could not have wanted this kind of senate, since it would not only detract from the principle of political equality, but it would also constitute a dangerous counter-power to the nation's will ${ }^{93}$. On the other hand, should the senate represent the same national will which the Chamber represented, then it would be entirely superfluous. Why choose for another elected assembly to represent the national will, if there already existed one ${ }^{94}$ ?

These arguments illustrate the republicans' monolithic understanding of the national representation: the nation, an abstract and universal entity, had but one indivisible will and, as such, it could only be represented by one elected, legislative chamber ${ }^{95}$. Republicans in and out of Congress urged the congressmen to reject the institution of the senate, to deny the monarch the right to dissolve the legislative chamber, and to provide him with a suspensive veto at most. They even endeavoured on multiple occasions to undo the congressional choice for a monarchy ${ }^{96}$. The position of the radicals equally shows that

$91 \quad$ Ibid, p. 487, 15/12/183o, de Robaulx.

$92 \quad$ Ibid.

93 In the same intervention, de Robaulx argued that this was actually what most advocates of the bicameral system tried to achieve: 'On craint que la grande propriété n'ait pas assez de représentants dans la chambre basse; on n'est pas content d'une disposition qui lui assurerait une juste représentation, on veut faire exprès pour elle une chambre haute' ('There is a fear that the landowners will not have enough representatives in the lower Chamber; there is discontentment over a disposition that would ensure them a just representation, some want to establish a high Chamber especially for them'): ibid, p. 487, 15/12/1830, de Robaulx (in fine).

94 Ibid, p. 487, 15/12/1830, de Robaulx.

95 Jottrand described the monocameralist understanding of the nation as 'un tout homogène où l'on n'aperçoit aucune spécialité bien tranchante ni de caste ni d'intérêts' ('a homogenous whole without sharp divisions of caste or interest'). Note that the majority of the unicameralists were republicans: ibid, p. 501, session of 15/12/1830; ibid, p. 508, 16/12/183o, Jottrand.

96 When it became clear that Congress would opt for a monarchy, Seron and de Robaulx proposed to organise a referendum. Yet, the majority in Congress was well aware of their strategic intentions and vehemently rejected the proposal. In February 1831, de Robaulx 
they had particular difficulties with the dissociation between the source of sovereignty and its exercise; between constituent and normal politics. They believed that to admit the hereditary principle in the exercise of sovereignty would be to violate sovereignty in its source.

Interestingly, the radicals shared their opposition against the multiplication of representation with their conservative opponents ${ }^{97}$. The Catholic newspaper Courrier de la Meuse claimed that monarchical and popular sovereignty were practically and conceptually irreconcilable ${ }^{98}$. Sovereignty meant supreme and indivisible power. It simply could not be distributed among the mass of individuals. And if it was, it would lead to chaos and demagogy. Moreover, if 'the people' was to be established as the ultimate, singular sovereign, it could retract at any given time the power attributed to the monarch ${ }^{99}$.

The radicals' objections were intensely debated in the press, but they were almost completely ignored by the congressmen, who by a large majority adopted constitutional monarchy with a bicameral legislature. It was a system that featured several aspects of modern representation: a multiplication of elected or non-elected representative actors with a certain degree of independence in the exercise of their function.

However, neither the choice for a representative government, based on an electorate-function, nor the rejection of the imperative mandate, stemmed from a presumed choice for 'national sovereignty'. The discussion on the binding nature of the representative mandate was motivated by practical considerations and by fear of popular demagogy in the context of specific debates (such as the exclusion of the Nassau dynasty). The same was true for the choice for a representative government, which was practically uncontested. And in the same vein, the preference for census suffrage was motivated by the idea of capacity, and not in any way related to the idea of a holistic, abstract nation.

A 'genuine' representation of the nation

In a modern conception of representation, where the nature of representation is virtual, the representatives no longer depend on their constituents: since the representatives are constitutionally appointed to represent the nation, their

made another fruitless attempt at proclaiming the republic: Huyttens, Discussions (supra, n. 31), vol. 1, p. 223-229, 20/11/1830, de Robaulx and Forgeur; Huyttens, Discussions (supra, n. 31), vol. 2, p. 512-514, 14/o2/1831, de Robaulx.

97 Deseure and Maes, 'All the Powers Emanate from the Nation' (supra, n. 26).

98 See also: Deseure, National Sovereignty (supra, n. 13).

99 Courrier de la Meuse, 04/11/1830, n. 266. 
power is almost automatically justified. Yet, as we have seen, the Belgian revolutionaries did not believe that the representation of the nation came down to an unlimited and unaccountable exercise of political power in the name of the sovereign people. Indeed, those who exercised sovereignty did not have any actual rights to sovereignty itself. In the Belgian Revolution, this was not merely a theoretical consideration.

The Belgian founding fathers were concerned that the national representation should effectively represent the actual nation and its collective interest. This concern was the logical outcome of a long advocacy under the Dutch rule for proportionate representation, corresponding to the present population ${ }^{100}$. This confirms yet again that they understood the nation not as an abstract being that conceptually differed from the contemporary population. ${ }^{101}$ If such were the case, the exact composition of the National Congress would have mattered less than it did. As it was, public debate regularly ensued over supposed flaws in the national representation caused by an inaccurate repartition of votes. In the run-up to the election of the Congress, the newspapers debated whether the inhabitants of those parts of the territory that had joined the revolt, but which were still partly under Dutch occupation, should have the right to vote. The newspaper Le Belge argued to the negative, stating that those inhabitants were not actually free, and that their votes would subsequently reflect the force of military occupation, rather than popular opinion. This situation would result in a distortion of the national representation ${ }^{102}$. Other newspapers argued to the contrary: excluding the occupied territories from the Congress constituted the real distortion of the majority view. The same reasoning underlies the debate about the lowering of the census for the countryside. Since the cities counted a lot more citizens who met the suffrage conditions than did the countryside, the latter risked being underrepresented in the national assembly.

100 The underrepresentation of Belgians in the Estates-General was an important point of contention. Although the Southern population was numerically superior to the North, both parts of the country had the same number of representatives. The Southern claim for proportional representation met with consistent refusal from King William I, who feared a Southern and Catholic majority in the Estates: E. Bos, Soevereiniteit en religie, Godsdienstvrijheid onder de eerste Oranjevorsten, Hilversum 2009, p. 145-146; G. Van Nifterik, On the idea of democracy in the Dutch Constitution Committees of 1814 and 1815 , Parliaments, Estates and Representation, 31 (2011/1), p. 30-31.

101 De Smaele, Omdat we uwe vrienden zijn (supra, n. 25), p. 20.

102 'Qu'en résultera-t-il ? Que la représentation nationale sera faussée ; que le véritable vœu du peuple, celui de la majorité sera peut-être méconnu' ('In what will this result? That national representation will be warped; that the real wish of the people, of the majority, may be ignored'): Le Belge, 28/101830, n. 301, Élections au Congrès National. 
Furthermore, the revolutionaries did not perceive the representative institutions in the constituted order as fully autonomous 'producers' of a national wish ${ }^{103}$. Unquestionably, the agency of the nation was achieved through its representatives, who 'filtered' and exteriorised the people's wishes and interests. But representation did not mean that the representatives expressed their own will in the name of an abstract and timeless nation. Although they were expected to discuss and deliberate about the interests of the country in order to make the best choice, their decisions still needed to reflect the majority view present in contemporary society. Le Courrier wrote about the Congress: 'sa sagesse répond à l'attente du pays et au vœu de l'immense majorité de la nation dont il est l'interprète'104.

In other words, the representatives did not construct the popular will ex nihilo. The nation - a substantial, yet rudimentary and collective entity, composed of a myriad of persons with diverse ideas - certainly had a will of its own, but it simply could not express these shared intentions by itself ${ }^{105}$. In order to express its will it needed to create institutions that would distil out of all the individual interests what was common in order to produce a 'national wish'. The same idea transpires in congressman Leclerq's intervention on representative monarchy:

Sous [la monarchie représentative], la nation intervient aussi dans ses affaires, mais cette intervention n'est qu'indirecte ; elle part du peuple, mais elle passe par les mains de ses élus; elle va se concentrer, s'épurer, si je puis dire ainsi, dans les mains des plus dignes et des plus intéressés au bien-être général ${ }^{106}$.

103 Le Hon e.g, stated in Congress: ‘[...] jusqu’au moment décisif, nous ne pouvons aliéner nos suffrages. Ils ne sont pas même à nous ; ils appartiennent à la patrie' ('[...] until the decisive moment, we cannot alienate our right to vote. It is not even ours; it belongs to the fatherland'): Huyttens, Discussions (supra, n. 31), vol. 2, p. 418, o2/o2/1831, Le Hon.

'[...] its wisdom responds to the expectation of the country and to the wish of the immense majority of the nation of which it is the mouthpiece': Courrier des Pays-Bas, 21/11/183o, n. 325 .

105 For the references of the congressmen to their introspective as 'translators of the national wish': Huyttens, Discussions (supra, n. 31), vol. 1, p. 118, 12/11/183o, de Foere; ibid, p. 178, 18/11/183o, Masbourg; ibid, p. 228, 20/11/183o, de Robaulx; ibid, p. 238, 22/11/183o, Abbé Verbeke; ibid, p. 245, 22/11/183o, de Muelenaere; ibid, p. 259, 22/11/183o, Masbourg (in footnote); ibid, p. 219, 20/11/183o, de Roo; ibid, p. 436, 14/12/183o, Fleussu; Huyttens, Discussions (supra, n. 31), vol. 2, p. 98-99, 11/o1/1831, de Liedel de Well; Huyttens, Discussions (supra, n. 31), vol. 3, p. 248, o3/o6/1831, Boucqueau de Villeraie; ibid, p. 26o, o3/o6/1831, Doreye; ibid, p. 333, 25/06/1831, Seron; ibid, p. 444, 04/07/1831, de Pélichy van Huerne; ibid, p. 496, o7/o7/1831, de Muelenaere.

106 'Under this form of government [i.e. representative monarchy], the nation also intervenes in its affaires, but this intervention is merely indirect; it starts from the nation, but it 
His colleague Lebeau expressed a similar thought when advocating ministerial responsibility: ministers were to govern according to the wish of the Chamber of Representatives, 'c'est-à-dire selon le vœu du pays qu'elle est censée représenter ${ }^{107}$. And Tiecken de Terhove, stressing the importance of the future electoral law, which should be a 'une représentation réelle de l'opinion publique' ('a real representation of the public opinion'), advocated its immediate draft and its integration in the Constitution ${ }^{108}$. Similar arguments were made concerning the establishment of a senate: Van Snick argued against it, claiming that a senate would isolate itself from the wishes and the needs of the people ${ }^{109}$. Blargnies was in favour of a high chamber, since it would prevent the representatives in the Chamber from concentrating power in their hands at the detriment of the nation, warping its will and eliminating any form of control. A single assembly would inevitably end up attracting all powers and enslaving the nation ${ }^{110}$.

In short, the genuine articulation of the national wish was an important point in the debates. Even if this may, on certain occasions, have been a rhetorical argument more than anything else, the fact remains that the instituted powers could not simply substitute the existent national wish with their own. This was all the more logical, considering the congressmen's awareness of the public opinion both within and outside of the Congress ${ }^{111}$. Their words were

passes through the hands of the elected; it is concentrated, purified, if I may say so, in the hands of those most worthy and most interested in the general wellbeing'. Leclercq does not distinguish between 'people' and 'nation': Huyttens, Discussions (supra, n. 31), vol. 1, p. 188-189, 19/11/1830, Leclercq.

107 'that is, according to the wish of the nation she is supposed to represent'. If the term 'censée' ('supposing') might allude to a fiction, this wording could also express Lebeau's normative assessment of the elective chamber's role. This seems to be confirmed by what Lebeau says moments earlier, when he describes the electoral colleges as 'cette partie de la nation qui a intérêt à l'ordre et intelligence des droits et des besoins du pays' ('the part of the nation that is interested in order and has knowledge of the rights and the needs of the country'). In May 1831 he stated that the representatives of the people were the 'interprètes fidèles de l'opinion publique et des vœux de la nation' ('truthful translators of the public opinion and the wishes of the nation'). Resp.: Huyttens, Discussions (supra, $\mathrm{n}$. 31), vol. 1, p. 208, 20/11/183o, Lebeau; Huyttens, Discussions (supra, n. 31), vol. 3, p. 348, 28/06/1831, credence signed by Lebeau.

108 His proposal was partly admitted: the immediate draft in a committee was adopted, whereas the insertion of the electoral law in the Constitution was rejected: Huyttens, Discussions (supra, n. 31), vol. 1, p. 558, 20/12/1830, de Tiecken de Terhove.

109 Huyttens, Discussions (supra, n. 31), vol. 1, p. 401, 13/12/1830, Van Snick.

110 Huyttens, Discussions (supra, n. 31), vol. 1, p. 408, 13/12/183o, Blargnies.

111 Several incidents in the Congress reveal the physical and mental proximity between the representatives and the represented, as well as the representatives' recognition of the latter. See e.g. Huyttens, Discussions (supra, n. 31), vol. 2, p. 318, 29/o1/1831, Surlet de Chokier; Huyttens, Discussions (supra, n. 31), vol. 1, p. 572-573, session of 21/12/183o. 
reacted to from the public gallery of the assembly room, copied in the press, and responded to by petitions. Also, the congressmen knew they would be judged by their peers after their return into civil society ${ }^{112}$. Moreover, they understood that inadequate choices on their part entailed the risk of occasioning a new popular revolution ${ }^{113}$.

The constituent debates indicate that direct interference by the nation was not completely excluded. Sometimes it was inevitable to resort to immediate agency by the nation. This was the case for instance when the instituted powers stopped legitimately exercising their authority in conformity with the will of the nation. When the political order was distracted and committed to issues that were unrelated to the preoccupations of the people, when it refused to engage with the national interests or when it violated the constitutional limits imposed by the nation, the latter had the exceptional right to manifest itself and to reclaim its sovereignty through resistance and insurgency ${ }^{114}$.

The idea of legal resistance, drawing on the provisions of the constitution, had been paramount in the discourse of the Belgian opposition under the United Kingdom of the Netherlands. The idea was radicalised and universalised in the revolutionary moment, when the protest against and subsequent

112 See e.g. Huyttens, Discussions (supra, n. 31), vol. 1, p. 187, 19/11/183o, Leclercq. See in the same vein de Gerlache's intervention concerning the members of the Provisional Governement: Huyttens, Discussions (supra, n. 31), vol. 2, p. 595, 25/o2/1831, de Gerlache. See also Van Snick's request to act his vote in the congressional minutes, 'parce que je ne veux pas supporter la responsabilité de la décision de l'assemblée vis-à-vis de mes commettants' ('because I cannot bare the responsibility of the assembly's decision vis-àvis my constituents'): Huyttens, Discussions (supra, n. 31), vol. 1, p. 639, 24/12/1830, Van Snick.

113 '[...] qui a fait la révolution? Les masses. [...] ces masses, si vous ne leur laissez pas la somme de bonheur à laquelle elles ont le droit de prétendre, seront peut-être tentées de comparer leur sort actuel à leur sort passé! et [sic] alors notre révolution est en péril' ('[...] who has made the revolution? The masses [...] but these masses, [...], if you will not give them the amount of happiness which they have a right to expect, might compare their actual fate with their former conditions! And then our revolution will be in peril'): Huyttens, Discussions (supra, n. 31), vol. 2, p. 446, o3/o1/1831, Forgeur. See also also Huyttens, Discussions (supra, n. 31), vol. 1, p. 176, 18/11/183o, Lardinois; ibid. p. 236, 22/11/183o, Blargnies; Huyttens, Discussions (supra, n. 31), vol. 3, p. 198, 31/05/1831, d'Elhounge.

114 The Courrier des Pays-Bas wrote that a violation of the constitutional limits by the government constituted in fact not so much a rebellion of the nation, as of the constituted powers. Inevitably, it entailed a struggle between the nation and the government, which could result either in national liberty or in absolute domination of the government over the nation: Courrier des Pays-Bas, o5/o3/1831, n. 64. See also C. Maes and B. Leijssenaar, Constituent Power in the Belgian National Congress and the 1831 Belgian Constitution, in: The People versus the Nation. Sovereignty, Civic Participation, and Constitutional Law in Belgium, ed. by B. Deseure, R. Geenens, and S. Sottiaux, Abingdon \& New York (in press). 
deposition of king William I was legitimised in terms of resistance against despotism $^{115}$. The National Congress' retroactive endorsement of the actions taken by the Provisional Government as de facto representative of the Belgian Nation in the transition period (October-November 1830) testifies to the general acceptance of this natural rights logic ${ }^{116}$. Resistance against despotism provided a higher legal norm than any constitutional order, a truth of which the first Belgian government, instated after the promulgation of the new constitution on 11 February 1831, was regularly reminded by more radical congressmen ${ }^{117}$.

This Lockean idea of resistance brings us to a final element, underpinning the Belgian revolutionaries' conception of representation, which was anchored in the republican tradition: the idea of control and contestation ${ }^{118}$. The people, which had entrusted the public authorities with governmental power, was entitled to continuously evaluate and potentially challenge these authorities for the exercise of their tasks. This vision of representation relied not so much on the mechanism of popular authorisation of governmental power, as on contestation and resistance ${ }^{119}$.

Press and congressmen alike insisted that the system instated by the Constitution could only work on the condition that the population actively surveyed the political class. Involvement in politics was imperative for all citizens, not only for the limited group of qualified voters. Without continuous control, the nation would effectively renounce its sovereign rights. Hence, the nation's intervention was not strictly limited to periodical elections. The sovereignty of

115 Deseure, Constitutional Precedence (supra, n. 18), p. 220-243; P. Van Velzen, De ongekende ministeriële verantwoordelijkheid (supra, n. 18), p. 422; E. Witte, De Grondwet van het Verenigd Koninkrijk der Nederlanden (1815) en het ontstaan van de Belgische Constitutie (1837), in: De Grondwet van het Verenigd Koninkrijk der Nederlanden van 1815, ed. by A. Alen A, A.W. Heringa, D. Heirbaut and C.J. Rotteveel Mansveld, The Hague and Bruges 2016, p. 43 .

116 Only later in the nineteenth century was the right of resistance projected on to the pre-revolutionary Netherlandish tradition of the ancient constitutions: B. Deseure, From Pragmatic Conservatism to Formal Continuity, Nineteenth-Century Views on the Old Regime Origins of the Belgian Constitution, Giornale di Storia Costituzionale, 32 (2016/2), p. 257277; De Dijn, A Pragmatic Conservatism (supra, n. 22); S. Marteel, Van 'oude constitutie' tot liberale grondwet, Het Belgische politieke natiebesef tussen 1815 en 1830, in: De erfenis van 1830, ed. by P. Rietbergen and T. Verschaffel, Leuven 2006, p. 35-52.

117 Deseure, National Sovereignty (supra, n. 13), p. 139-147; Maes and Leijssenaar, Constituent Power (supra, n. 114).

118 For the contestatory element in the republican tradition, see P. Pettit, Republicanism, A theory of freedom and government, Oxford 1997, p. 200-202.

119 Ibid, p. 202. 
the nation only became true when public opinion - 'la reine du monde'-permanently judged and guided governmental action ${ }^{120}$.

This belief was clearly expressed at the occasion of the institution of the National Congress. The Revolution had shown that the population at large was ready to sacrifice its own private interests for the wellbeing of society. After the active phase of the revolution, it was up to the National Congress to decide over the nation's destiny and to establish a new order of things. The Courrier des Pays-Bas reminded its readers that it was nevertheless essential for the population to continue its active engagement with the public cause:

[...] bien loin que les hommes religieux et attachés aux principes d'ordre et de légitimité, doivent se retirer des affaires, il leur incombe désormais [...] une obligation rigoureuse de s'en occuper. Les plus chers intérêts de la patrie vont être débattus, un nouvel ordre de choses va s'établir, d'où dépendra notre avenir et celui de nos enfants et de nos neveux. Malheur donc à l'homme de bien qui se retire ! Malheur à celui qui préfère sa tranquillité au bien-être général ! Ce bien, dans la crise où nous sommes, ne s'opère que par la réunion des efforts des hommes de bien ${ }^{121}$.

This involvement should not be limited to the constituent moment, when momentous choices were made. 'Tout le monde au sortir du combat a été généreux, désintéressé', congressman Van Meenen warned his fellow congressmen. 'Mais attendez que le calme soit rétabli, alors chacun de nous commencera à songer à ses petites passions, à ses petits intérêts'122. Now that sovereignty was vested in the elected chambers, the Courrier de la Meuse wrote, it was essential for all 'enlightened spirits and lovers of liberty' to control the chambers, just like they needed to control the government. If the law was made in the name

120 Huyttens, Discussions (supra, n. 31), vol. 1, p. 217, 20/11/1830, de Haerne; Huyttens, Discussions (supra, n. 31), vol. 2, p. 340, 31/o1/1831, Van Snick.

121 ' [...] the religious men and those who are attached to the principles of order and legitimacy should not withdraw from [public] affairs, from now on [...] they have the rigorous obligation to take care of it. The dearest interests of the homeland will be debated, a new order of things, on which our future and that of our children and cousins depends, will be established. Woe to the man who withdraws! Woe to him who prefers his personal tranquillity over the general well-being! In the crisis which befalls us, prosperity will only be accomplished thanks to the efforts of the obliging men': Courrier des Pays-Bas, 29/10/183o, n. 292.

122 'In the heat of revolution, consensus reigns. But wait until the calm has returned and you will see everyone strive for his own petty interests and passions': Huyttens, Discussions (supra, n. 31), vol. 1, p. 429, 14/12/183o, Van Meenen. 
of the nation, the nation needed to keep a close watch on the lawmakers ${ }^{123}$. This was all the more so since the Congress principally admitted publicity in the functioning of those institutions ${ }^{124}$.

The domain of politics belonged not exclusively to the elected representatives, nor even to the electorate. Public opinion needed to inform politics, and all enlightened citizens had a share in its formation. If a nation was to be enlightened, the newspaper L'Union belge affirmed, then government had to be grounded in public opinion:

[...] nous Belges [...] nous savons que chez une nation qui pense, chez une nation éclairée, l'opinion publique est et doit être la règle du gouvernement ; nous savons que chez une nation qui sait apprécier la liberté et qui en est digne, la règle de l'opinion publique est l'intérêt permanent de la société, le salut et l'utilité de tous ${ }^{125}$.

For the Courrier des Pays-Bas, the real national wish could only be discovered by consulting public opinion. It was therefore essential for the citizens to publicly debate politics:

C'est maintenant à l'opinion publique à préparer par une discussion libre et calme, les voies qui doivent nous conduire à un état définitif, expression du vœu national. Que nul système n'aspire à prévaloir d'une manière

123 Courrier de la Meuse, o9/12/183o, n. 296.

124 'Une nouvelle garantie de son indépendance [Sénat] sera la publicité de ses séances et de ses actes. Cette publicité servira de frein à l'émission de principes contraires aux libertés générales. En face de la nation, on n'osera pas ourdir des trames que la désapprobation du peuple frapperait immédiatement d'impuissance ; l'opinion publique en ferait justice, et nous vivons dans un siècle où l'opinion publique est la reine du monde' ('The publicity of its [the Senate's] sessions and actions will be the new guarantee of its independence. This publicity will check those principles that harm the general liberties. In front of the nation, no one will dare to plot intrigues that the people's disapproval would immediately render powerless; public opinion would do justice to it, and we live in a century in which public opinion is the queen of the world'): Huyttens, Discussions (supra, n. 31), vol. 1, p. 448, 14/12/1830, H. Vilain XIIII. 'No one should remain in the shadows; the people must be able to judge by itself the way in which we fulfil the mandate it has entrusted us with' ('II faut que personne ne reste dans l'ombre; il faut que le peuple puisse juger par lui-même de la manière dont on s'acquitte du mandat qu'il nous a concédé'): ibid, p. 132, 13/11/183o, Tiecken de Terhove.

125 ' [...] we Belgians [...] we know that in a nation that thinks, in an enlightened nation, public opinion is and should be the rule of government; we know that in a nation that knows how to appreciate liberty and is worthy of it, the rule of public opinion is the permanent interest of society, the salvation and the usefulness of all': L'Union belge, 19/11/183o, Congres national - Constitution, Sixième Lettre. 
trop absolue; que des diverses nuances d'opinion sorte un éclectisme politique propre à concilier toutes ${ }^{126}$.

This political eclecticism was the only way to sustain a political regime upholding the unionist polity of the liberals and the Catholics. Still, the insistence on public debate has a republican flavour. Debate in the public sphere was essential for enlightening the people's representatives on the will of the nation. Debate needed to be moderate and reasonable, but nevertheless thorough. Le Belge wrote: 'ne renonçons pas au droit d'éclairer cette assemblée et de lui faire connaître la volonté du peuple par des observations modérées et fondées sur le raisonnement'127.

Several channels stood at the public's disposal to contribute to the formation of public opinion and to communicate it to the representatives. First among these channels was, quite evidently, the press. For the revolutionaries, the freedom of the press constituted by far the most important of political liberties $^{128}$. It was the very incarnation of liberty and reason. In the constituent debate, Nothomb proposed to insert an additional sentence, aimed at prohibiting any preventive measure against criticism of the public authorities ${ }^{129}$. According to Nothomb, society had reached an era 'où nul n'exerce la dictature de l'intelligence, et où la raison de chacun s'est proclamée souveraine' ${ }^{130}$. The

126 'It is now for public opinion to prepare, through a free and calm discussion, the ways that will lead us to a definitive state, the expression of the national will. No system should aspire to prevail in too absolute a way; from the various nuances of opinion a political eclecticism should arise, able to reconcile them all': Courrier des Pays-Bas, 08/10/1830, n. 281 .

127 '.... let us not renounce the right to enlighten this assembly and to inform it of the will of the people by means of moderate and reason-based observations': Le Belge, 11/11/1830, n. 315 .

$128[\ldots]$ après vous être assuré une garantie dans l'omnipotence de l'opinion par la presse, et dans la presse par le jury, pouvez-vous craindre encore pour la liberté?' ('[...] after having assured yourselves of the guarantee of the omnipotence of the opinion through the press, and of the press through the jury, can you still fear for liberty?'): Huyttens, Discussions (supra, n. 31), vol. 1, p. 471, 15/12/183o, de Gerlache. De Haerne qualified the press as 'le grand levier au moyen duquel, aujourd'hui, on dirige le monde' ('the great lever by which, today, one directs the world'); Verduyn as 'la [liberté la] plus vitale et la plus sacrée, parce qu'elle est la sauvegarde et le palladium de toutes les autres [libertés]' ('the safeguard and the palladium of all the others [liberties]'); and Devaux as 'la plus importante de nos libertés'('the most important of our liberties'): resp. ibid, p. 66o, 27/12/183o, de Haerne; ibid, p. 653, 26/12/183o, Verduyn; ibid, p. 643, 24/12/183o, Devaux.

129 Huyttens, Discussions (supra, n. 31), vol. 1, p. 643, 24/12/1830, Nothomb.

130 '[an era] where no one will exercise the dictatorship of intelligence, and where everyone's reason is proclaimed sovereign'. Nothomb's reference to the 'individual' reason is key, as it implicitly marks the Belgian disavowal of the French doctrinaires' sovereignty of reason 
press was there to inform its readers, but equally to critically evaluate governmental action and to denounce judicial abuses or legislative problems: 'Vousvoulez [sic] d'autres garanties encore?', liberal congressman Defacqz asked his colleagues: 'Vous les trouverez et dans la presse, sentinelle infatigable, organe puissant de l'opinion qui signale et flétrit l'abus de quelque part qu'il procède, et dans le sens judicieux et droit de la nation qui s'empressera de désavouer de fausses mesures auxquelles son intérêt même servirait de prétexte'131.

Yet, the press did not only disclose abuses. It facilitated the reciprocal circulation of ideas horizontally, as well as vertically; between the citizens, and between them and the constituted powers. It was the newspapers' task to debate politics and thus to help the representatives and the government understanding the national wish. This is how Le Belge interpreted the Provisional Government's decision to have the draft Constitution published in all the newspapers: 'The provisional government hastens, via the newspapers, to provide it [the draft] to the public in order to inform itself of the true state of opinion concerning the discussion that the project will raise'132. In a modern state, com-

- which was not based on the individual conscience, since it departed from the inevitable human fallibility - and the connection with Benjamin Constant's idea of human perfectibility, entailing a liberalism of 'reason' through individual assessment: L. Jaume, L'individu effacé, ou, Le paradoxe du libéralisme français, Paris 1997, esp. p. 297 with fn. 195. For the discussion in Congress see esp. Huyttens, Discussions (supra, n. 31), vol. 1, p. 651657, Nothomb, de Robaulx, Devaux.

131 'Do you want more guarantees still? You will find them in the press, that tireless sentinel, that mighty organ of opinion, which reports and exposes abuses from wherever they proceed, and in the right and judicious sense of the nation, which will quickly denounce the false measures for which its own interest would serve as a pretext': Huyttens, Discussions (supra, n. 31), vol. 1, p. 423, 14/12/183o, Defacqz. See also Huyttens, Discussions (supra, n. 31), vol. 1, p. 627, 24/12/1830, Morel-Blanneel; ibid, p. 656, 24/12/183o, de Foere; Huyttens, Discussions (supra, n. 31), vol. 2, p. 502, 11/o2/1831, Destouvelles. See also S. Marteel, Constitutional Thought under the Union of the Netherlands, The 'Fundamental Law' of 1814-15 in the Political and Intellectual Context of the Restoration, Parliaments, Estates and Representation, 27 (2010), p. 9 o.

132 '[Le gouvernement provisoire] s'empresse de le livrer au public par la voie des journaux, afin de s'éclairer lui-même, pour la discussion que le projet soulèvera, de l'état véritable de l'opinion': Le Belge, 3०/10/183o, n. 303. One year earlier, Le Belge differentiated between the law, which was supposed to represent the national will, and the national will itself, which continuously acted upon the law through the press and through the electorate: 'Ainsi, en définitif, ce n'est pas dans le roi, c'est dans la nation que réside la souveraineté: elle en a délégué certaines parties, et tout ce dont elle n'a pas disposé reste dans le domaine de la loi, qui est censée exprimer la volonté nationale, et sur laquelle la volonté nationale peut exercer continuellement son action par la presse et par les élections' ('And so, in the end, it is not in the king, but in the nation that sovereignty resides: it has delegated certain parts of it, and everything of which it has not disposed remains in the domain of the law, which is supposed to express the national will, and upon which the 
posed of a myriad of individuals, only the press could enable the exchange of ideas and the formation of a common public opinion, important enough to weigh on governmental decision-making. It was the medium par excellence for converging the multiplicity of opinions into a 'national' public opinion, simultaneously creating a connection between the citizens and the government ${ }^{133}$. At the same time, the press had an educative role to play on the political level: in order to create a stable institutional system, it was essential to inform the citizens about political affairs and the working of their national institutions. No medium was better suited for that task than the press ${ }^{134}$.

The 'droit sacré de pétition' ('sacred right of petition') $)^{135}$ and the right of association were understood in the same way. These political rights were not much debated in the Constitutional Commission or in Congress ${ }^{136}$. Their importance for the revolutionaries is nevertheless clear from the historical context. The massive petition waves against the Dutch government in the late 1820 's had been an essential steppingstone in the creation of an oppositional public spirit. The revolutionaries were aware that petitions were not only an instrument of complaint, but also saw them as a participatory channel, even as a right of initiative ${ }^{137}$. In this regard, the Courrier des Pays-Bas argued that the right of petition was a part of the legislative power that belonged to every Belgian. Staging petitions campaigns among the non-enfranchised population was a way of making the citizens take part in the legislative process. As such, the right of petition was 'une expression légale de l'opinion publique' ('a legal expression of the public opinion') ${ }^{138}$. It formed an excellent complement to the press in developing an efficient public opinion that could inform,

national will can continuously exercise its action through the press and through elections'): Le Belge, o3/10/1829, n. 276, Où réside la souveraineté?.

B. Delbecke, De lange schaduw van de grondwetgever, Perswetgeving en persmisdrijven in België, 1831-1914, publ. doct. thesis, Law, K.U. Leuven, Leuven 2010, p. 56.

$134 \quad$ Ibid, p. 56.

135 Huyttens, Discussions (supra, n. 31), vol. 2, p. 278, 27/o1/1831, de Robaulx.

136 There was almost no discussion on the right of petition, whereas the discussion relating to the right of association focused primarily on the religious congregations: Huyttens, Discussions (supra, n. 31), vol. 1, p. 666, 27/12/1830; Huyttens, Discussions (supra, n. 31), vol. 2, p. 472-478, 05/o2/1831. For a more critical assessment: Bourgaux, La démocratisation (supra, n. 52), p. 254-264.

137 P. Errera, Traité de droit public belge, Paris 1909, p. 179; C. Faider, Le droit de pétition, Discours prononcé à l'audience solennelle de rentrée de la Cour de cassation de Belgique le 16 octobre 1882, Pasicrisie, vol. 1, 1882, p. 2 and p. 6; E. Witte, De constructie van België 18281847, in: Nieuwe geschiedenis van België, ed. by E. Witte, J.-P. Nandrin, E. Gubin and G. Deneckere, vol. 1, Tielt 2005, p. 70.

138 Courrier des Pays-Bas, 27/07/1829, n. 208, Des états provinciaux et de leurs attributions. 
but also control the government ${ }^{139}$. Le Politique supported this view, writing that 'Dans cet appui imposant que la nation leur prête, ses représentans [sic] reconnaîtront à la fois et quelle est aujourd'hui la force de l'opinion, et ce qu'on peut espérer dans l'avenir' ${ }^{140}$. But the greatest advantage of the petition right was that it could ultimately constitute an effective instrument of collective action and responsiveness, especially when the community's griefs were being ignored ${ }^{141}$.

The right to assemble and the freedom of association were also considered essential for the formation of the public spirit. Associations were yet another form of bottom-op organization intended to influence the public sphere. They had proven very effective in the run-up to the revolution, so obviously the revolutionaries did not fail to provide them with constitutional protection ${ }^{142}$. Le Belge defined their mission as follows: ' $1{ }^{\circ}$ à éclairer le gouvernement sur ses erreurs, $2^{\circ}$ à lui indiquer les mesures utiles à prendre dans les circonstances difficiles où nous nous trouvons, et $3^{\circ}$ à former, à développer le plus possible l'esprit public'143.

Lastly, a popular jury was established for press delicts and political crimes, as well as for the worst criminal offences. The main purpose of the jury was to provide a guarantee against despotic tendencies in the government, which might be tempted to muzzle the public opinion through the judicial power. Hence the attribution of press delicts and political crimes to lay judges, who were considered to represent public opinion ${ }^{144}$, and to be more independent

139 Courrier des Pays-Bas, 27/07/1829, n. 208, Des états provinciaux et de leurs attributions.

140 'The representatives will recognise in this impressive support which the nation provides them [i.e. the petition waves] what the force of public opinion is and to what extent it reaches, as well as what we might hope for the future': Le Politique, 28/01/1829 as cited in Delbecke, De lange schaduw (supra, n. 133), p. 55 .

141 P. De Keyser, Het petitierecht afgestoft, Tijdschrift voor Bestuurswetenschappen en Publiekrecht, 8 (2000) p. 596-599.

142 Old articles 19 and 20 of the Constitution.

$143{ }^{\prime} 1^{\circ}$ to illuminate the government about its mistakes, $2^{\circ}$ to indicate the useful measures to take in the difficult circumstances we are facing, and $3^{\circ}$ to form, to develop as much as possible the public spirit': Le Belge, 20/10/1830, n. 293 .

144 Future congressman and representative in the Dutch States-General Théophile Fallon described the jury in the Second Chamber as 'une espèce de représentation nationale, qui associe, en quelque sorte, l'opinion populaire à l'autorité de la chose jugée' ('a sort of national representation, which, in a way, associates public opinion to the force of res judicata'). Another future congressman, baron de Sécus, defined its decisions as 'le jugement du pays [...] propre aux gouvernemens représentatifs parce que là seulement il peut être véritablement le jugement de la société' ('the judgement of the country [...] proper to representative governments, by which it can be truly the judgement of society'). Stress from de Sécus: resp. Le Belge, 16/04/1829, n. 106; Le Belge, 11/04/1829, n. 101. See also Huyttens, Discussions (supra, n. 31), vol. 3, p. 576-577, 18/07/1831, Raikem. 
from and more objective than governmental authorities ${ }^{145}$. The jury was especially useful, as it could deviate from potentially despotic points of view of the government and undo illegitimate prosecutions ${ }^{146}$. Additionally, the congressmen argued that the jury contributed to the formation of a public spirit - a shared interest in (participation in) the public cause - and that it would enable a 'moral fusion' of the citizen, necessary for the stability of the representative government ${ }^{147}$. These effects were also elementary for the concretisation of a public opinion that was resilient against potential abuses of the constituted powers.

However, these 'institutions' exteriorised the national wish, they did not form the national decisions by themselves ${ }^{148}$. They all depended on representative institutions that materialised this wish through deliberation. It did not follow that the role of public opinion was reduced to elections. The griefs or the claims in petitions, and the discussions in the newspapers and in the political clubs and literary cafés could indeed contribute to the decision-making process $^{149}$. And the decisions of the representatives still had to pass the test of public opinion afterwards. The relation between the representative institutions and public opinion was, in other words, a responsive and dialectic one: 'Dans ce gouvernement, quand il est bien organisé, la loi est le résultat de l'opinion publique éclairée, exprimée par les élus du peuple, par la presse, par les pétitions', Blargnies asserted in the Congress ${ }^{150}$. With direct and popular elections, and with the guarantees of the contemporary era like the responsibility of the governing body, the jury, the judicial order, the civic militia, the freedom

145 See in this respect especially the speeches of Charles Le Hon and de Gerlache in the Second Chamber of the States-General: resp. Le Courrier des Pays-Bas, 25/04/1829, n. 115; Le Catholique des Pays-Bas, 19/04/183o, n. 97.

146 Huyttens, Discussions (supra, n. 31), vol. 2, p. 232 in fn. (1), 22/o1/1831, de Robaulx.

147 Le Belge, 'Du jury', 31/o3/1829, n. 9o. See also the earlier speeches from Goswin de Stassart and Charles Le Hon of April $13^{\text {th }}, 1829$ in the Second Chamber of the Estates-General, as published in Le Belge, 15/04/1829, n. 105.

148 'Les renvois de pétitions [au bureau des pétitions] n'ont jamais été considérés comme décisions, dans aucune chambre délibérante, car ils ne lient personne' ('Since they are non-binding, the referrals of petitions [to the bureau of petitions] have never been considered decisions, in neither of the deliberative chambers'): Huyttens, Discussions (supra, n. 31), vol. 2, p. 501, 11/o2/1831, Lebeau.

149 '...] Thanks to the liberty of the press, we will always be reminded that the nation must approve of the ministers and the chamber' ('[...] la liberté de la press. Grâce à elle, on ne tardera jamais à savoir qu'il faut que la nation approuve les ministres ou la chambre'): Huyttens, Discussions (supra, n. 31), vol. 1, p. 395, 13/12/1830, Comte de Celles.

150 'In this government, when it is well organised, the law is the result of the enlightened public opinion, expressed by the people, by the press, by the petitions': ibid, p. 238 , 22/11/1830, Blargnies. 
of education and of the press, de Roo exclaimed, 'vous n'aurez que la volonté de la nation tout entière'151.

The above goes to show that a republican concern for public involvement in politics was very present in the debates. The active development of the public spirit counted as an essential component of constitutional monarchy. The extent of popular involvement in the public opinion clearly went beyond that of the electorate, so as to include 'all enlightened spirits'. All of this reflects a conception of the nation in which political involvement of society at large belonged to the core of the political system. The permeability of the representative system ensured that the exercise of sovereignty not only became 'national', but also remained the 'genuine' expression of the nation's will.

\section{Conclusion}

The primary goal of the Belgian founding fathers was to prevent individuals or particular groups from usurping governmental power at the expense of the community and the individual rights of citizens. The constitution of a national representative system, based on the sovereignty of the Belgian people, was imperative. Performing their constituent work under the pressure of time and revolutionary circumstances, the drafters borrowed useful elements from different contexts ${ }^{152}$. Various early nineteenth-century political theories stood at their disposal. Although they constructed an internally coherent political system, the constitution was based less on abstract principles than on ad hoc procedure ${ }^{153}$. This eclecticism in intellectual sources may have contributed to the later confusion in the Belgian doctrine, resulting in an explanation of the representative government which is not supported by the spirit of the original debates.

We have argued that the Belgian founding fathers understood popular sovereignty as power from below, but simultaneously considered representation

$151 \quad$ '[...] you will simply have the will of the entire nation': ibid, p. 220, 20/11/1830, de Roo.

152 E. Descamps, La mosaïque constitutionnelle, Essai sur les sources du texte de la Constitution belge, Leuven 1891; H. de Smaele, Eclectisch en toch nieuw, De uitvinding van het Belgisch parlement, Bijdragen en Mededelingen tot de Geschiedenis der Nederlanden, 120 (2005/3), p. 408-416; J. Gilissen, Die belgische Verfassung von 1831, Ihr Ursprung und ihr Einfluss, in: Beiträge zur deutschen und belgischen Verfassungsgeschichte im 19. Jahrhundert, ed. by Werner Conze, Stuttgart 1967, p. 38-69.

153 Descamps, La mosä̈que constitutionnelle (supra, n. 152), p. 51; W. Van den Steene, De Belgische grondwetscommissie (oktober-november 1830), tekst van haar notulen en ontstaan van de Belgische grondwet, Brussels 1963, p. 6o. E.g. Huyttens, Discussions (supra, n. 31), vol. 1, p. 324, 11/11/1830, de Gerlache. 
and direct elections as necessary conditions for the realization of the sovereignty principle. Their understanding of the representative system was certainly indebted to the modern interpretation of representation, introduced on the continent with the French Constitution of 1791. As explained above, this entailed virtual representation and the multiplication of representative actors. It also favoured suffrage restrictions and disapproved the binding nature of the representative mandate. But even though the representatives were supposed to materialise and canalise the national wish, the Belgian congressmen did not understand this wish as an arbitrary creation. It was clear to all that the representation of the nation was not merely a juridical function. Parliament did not artificially construct the national wish ad libitum. Nor were its decisions considered to be the irrefutable expression of the national wishes and interests. The nation had a will of its own. Through various participative channels, public opinion constantly evaluated the representatives' decisions.

The Belgian Constitution of $183^{1}$ is often described as a turning point in the history of constitutional monarchy, due to its limitation of royal power, its introduction of ministerial responsibility and its strong representative structures, opening the way towards a parliamentary regime. ${ }^{154}$ However, the republican and contestatory elements of the new state system, ensuring effective control of the government by the entire enlightened population, was certainly as innovative in light of contemporary European state theory. In France, doctrinaire thinking increasingly loosened up the ties between the national representation and the living population, substituting national sovereignty with the sovereignty of reason and justice ${ }^{155}$, while in the Kingdom of the Netherlands a resurgence of national feeling in defense of king and constitution, following the Belgian Revolution, stifled the evolution towards a more national representation for about twenty years ${ }^{156}$.

The aforementioned elements have largely been overlooked in Belgian doctrine, which has mainly focussed on the lack or the rejection of (direct) participative elements. In the original spirit of the Constitution, public opinion articulated its assessment of representative government through the press, but

154 H. Dippel, Modern constitutionalism, an introduction to a history in need of writing, Tijdschrift voor Rechtsgeschiedenis, 73 (2005), p. 153-169; J. Gilissen, La Constitution belge de 1831, ses sources, son influence, Res Publica, 10 (1968), p. 135-141; Mirkine-Guetzevitch, Mille huit cent trente (supra, n. 24), p. 241-256.

155 Bacot, Carré de Malberg (supra, n. 10), p. 119; P. Brunet, Vouloir pour la nation, Le concept de représentation dans la théorie de l'Etat, Paris 2004, p. 33.

156 Koch, Le Roi décide seul (supra, n. 18), p. 50; N.C.F. van Sas, Het Grote Nederland van Willem I: een schone slaapster die niet wakker wilde worden, in: Staats- en natievorming in Willem I's koninkrijk (1815-1830), ed. by C.A. Tamse and E. Witte, Brussel 1992, p. 181. 
also through petitions and associations. And when public opinion stirred, the parliamentary representatives were expected to respond. When they failed to do justice to the grievances, other representatives were qualified to address the issue: the king could dissolve Parliament or pronounce his veto when he believed that the assembly's actions did not serve the national interest. The electorate would then indirectly speak up again by sending new representatives. The jury for its part corrected oppressive governmental action by assessing press or politically related crimes. The king's action was subject to parliamentary control and necessitated ministerial countersign. If all of this failed, and only then, the nation could ultimately resist and directly take matters into its own hands. Or in the words of Charles de Brouckère: '[...] l'opinion publique, c'est-à-dire la nation, l'emportera donc toujours'157.

157 '[...] public opinion, namely the nation, will always prevail': Huyttens, Discussions (supra, n. 31), vol. 1, p. 427, 14/12/183o, C. de Brouckère. 